\section{Who goes to Oxbridge?}

SIR - It is true ("Who goes to Oxbridge?", Nature 24 March, p.277) that Oxford and Cambridge selection procedures are being criticized for the apparently excessive number of students admitted from the independent fee-charging "public" schools, as compared with those from the state maintained schools. At Cambridge, for example, 48 per cent of those accepted in 1982 came from independent schools, attended by only about 5 per cent of their age group. This is the basis for the claim that the two ancient universities, as well as being admittedly "centres of excellence", are "also seats of privilege and are thus a baleful influence on British society as a whole', to quote from your article.

Oxford and Cambridge colleges have for many years been trying hard to select the best from among their applicants for admission as judged by purely academic standards and regardless of the schools they come from; and they try also to find promising candidates who may not have been well taught at school.

The Cambridge examination statistics are now published in a form from which some objective assessment may be made of any bias still remaining in the admissions system. Last year a special issue of the Reporter analysed the 1,930 men and 724 women who had completed their Part II (Final) Tripos examinations by, inter alia, the types of school from which they had been admitted, almost all in October 1979. Taking men and women together, 1,068 came from maintained schools and 862 from the independent sector, with a further 490 from "direct grant" schools and 234 "others", mostly from abroad. (The direct grant schools, which used to be a source of good candidates, were highly selective in their own admissions at the age of $11+$, and in 1979 these were being phased out in favour of the comprehensive system of state education, which was to be entirely non-selective. Many of the more successful of the old direct grant schools chose to become independent.)

Looking simply at the results of candidates from maintained and independent sectors, 14.6 per cent of the 1,068 maintained school candidates were placed in Class I in the Part II examinations, significantly better that the 10.9 per cent of firsts for the independent school girls, compared with $\mathbf{8} .8$ per cent for the $\mathbf{3 2 9}$ from maintained schools. (Women at Cambridge, incidentally, consistently get fewer firsts than do men but, since they also get fewer thirds, the average performance of the two sexes is about the same.) Thus the maintained schools' advantage here is evidence for some bias against them in the admissions three years before, but the effect is not a large one: about 18 more of over 1,000 maintained school candidates finished in Class I than would have been expected had the results for the two types of school been exactly the same.

Are relatively undeserving young ladies and gentlemen from public schools contriving to get places at the expense of worthier but less well taught candidates from the non-fee-paying sector? If so, this should show in their final examination results. Very few fail completely nowadays at Cambridge, with less than 2 per cent appearing under the two headings of "Allowances" towards the Ordinary (not Honours) degree, and of "Others" which include withdrawals for non-academic reasons as well as outright failures. But anyone who can do no better than Class III should probably also be counted as an admissions mistake, having got the place in preference to someone else who ought to have done better. Doing the same analysis as for Class I on the Third Class results, plus the few Allowances and Others, shows that 9.5 per cent of those admitted from maintained schools appear in this relatively unsatisfactory category, as compared with 9.2 per cent from independent schools, the difference not being statistically significant.

So if it can be agreed that Cambridge ought to be selecting the academically best of those who apply for admission, it seems that any bias that can be detected in these statistics is really very small indeed. Critics might be hard put to suggest a way of achieving fairer results.

\section{Gonville and Caius College,}

C.B. GOODHART

\section{Cambridge, UK}

SIR - I have read your editorial on Oxbridge (Nature 24 March, p.277), and I agree with you that the danger is that the universities will trim their sails to the wind so that they damage themselves, and by extension British education as a whole.

But that is about as far as my agreement goes. It seems to me that you propose a recipe for the disaster you seek to avoid.

\section{Department of Chemistry}

and Applied Chemistry,

University of Natal,

Durban, South Africa

\section{Bedford College}

SIR - May I take you up on an inaccuracy in the article "Merger, merger everywhere" (Nature 31 March, p.369). Bedford College is not only transferring its science teaching to Royal Holloway College but is merging completely with Royal Holloway to form a new college of about 3,000 students in the faculties of arts, music and science including the social sciences. We hope that through this merger we shall achieve a college which is strong and vigorous in both teaching and research. L.P. TURNBULL

Bedford College, (Registrar)

\section{London NWI, UK}

\section{Permissions granted}

SIR - I have recently completed a book, Quaternary Paleoclimatology, and have thereby become aware of the problems authors now face over gaining permission to reproduce copyrighted material. To reproduce a figure directly you must first write to the copyright holder, generally the journal or publisher. This would seem to be straightforward enough; however, most of these organizations require that you contact the authors and obtain their permission also. What, then, is the purpose of journals requiring that authors sign over copyright permission to them?

Furthermore, some journals (such as Science) require that a fee be paid for each figure permission granted. Presumably the authors whom the journal requires that you contact could do the same. In my case, some have requested copies of the book when published. Although each fee may be small, in a large book fees may easily mount up to $\$ 1,000$ or more, and this can only result in a higher price for the book. Other, more enlightened, organizations give carte blanche permission providing adequate citations are given, thereby avoiding masses of paperwork and accounting. In my case alone correspondence has involved literally hundreds of letters back and forth and collectively has probably consumed hundreds of man-hours and many thousands of dollars in secretarial costs and so on. It has certainly been the most frustrating aspect of writing the book. Surely it is in the best interests of the scientific community for publishers to state prominently in each journal that permission to reproduce one or two figures per article is automatically granted providing proper credit is given. This would aid communication, save time and money and avoid a great deal of aggravation for authors

RAYMOND S. BRADLEY

Department of Geology and Geography, University of Massachusetts, Boston, USA

- Nature's policy, like that of many other journals, stems from the belief that it is in the interests of the scientific literature and of the authors who contribute to it that copyright should be transferred to journals so that authors' work can then be protected. The matter is all the more important when new printing techniques facilitate piracy and illicit copying. The need that those wishing to reproduce material should also consult the original authors is more than a mere courtesy. For what it is worth, Nature does not make a charge in granting reasonable requests to reproduce single figures. The administration of permissions is more burdensome for busy journals such as Nature than even for Professor Bradley. Editor, Nature. 